\title{
Geochemistry of thallium in lead-zinc tailings
}

\author{
D.G. Allen MBS Environmental Pty Ltd, Australia
}

\begin{abstract}
Procedures for characterising mining wastes in Western Australia tend to focus on potential for producing acid rock drainage (ARD). However, many types of mining waste produce neutral or slightly alkaline drainage, which is usually considered environmentally benign from a geochemical perspective. This paper provides an example of potential contamination of the environment by the heavy metal thallium in alkaline seepage from lead-zinc mines. By understanding the geochemistry of thallium and other potential contaminants, an appropriate cover design for two tailings storage facilities (TSFs) in the north of Western Australia have been developed. The effectiveness of the soil covers has been demonstrated in a controlled field trial and by ongoing groundwater monitoring.
\end{abstract}

\section{Introduction}

Numerous lead-zinc sulphide deposits of the Mississippian Valley type are known to occur within the Lennard Shelf and several have been mined in recent years. The Lennard Shelf extends for approximately $350 \mathrm{~km}$ from near Derby to $100 \mathrm{~km}$ southeast of Fitzroy Crossing. MBS Environmental (MBS) has contributed to several lead-zinc projects; from submission of Mining Proposal for approval by Government regulators to closure and rehabilitation.

Comprehensive geochemical evaluation of process tailings, waste rock and soil materials from two mine sites was undertaken prior to planning for a suitable cover design to rehabilitate the tailing storage facility (TSF) at each mine site. The TSF at one of these sites was rehabilitated in 2005. The second TSF is currently being rehabilitated.

Testing of waste rock and process tailings using conventional acid rock drainage (ARD) laboratory test procedures indicated that potential for acid drainage from waste rock stockpiles and both TSFs was extremely low. However toxicants can also be released from chemical weathering of waste rock and tailings materials without generation of acidity. Some metals and metalloids are equally soluble under alkaline or neutral conditions as they are under acidic conditions. The Global Acid Rock Drainage (GARD) Guide identifies three types of mine drainage with the following approximate thresholds:

- $\mathrm{pH}$ greater than six: neutral mine drainage (NMD) and saline drainage (SD)

- $\mathrm{pH}$ less than six: acid mine drainage (AMD)

- Sulphate concentration of 1,000 mg/L: threshold between NMD and SD.

Figure 1 shows the domains of ARD, NMD and SD as functions of sulphate concentrations and $\mathrm{pH}$.

Several years of monitoring profiles of tailings stored in each TSF during the operational phase of the both mine sites indicated oxidation of tailings released several metals and metalloids in to the tailings porewater. Of particular interest was the heavy metal thallium, a contaminant occasionally encountered in other Mississippian Valley Type lead-zinc deposits in other countries, but rarely encountered in Australia.

This paper presents the results of an investigation of the geochemistry of thallium in lead-zinc tailings and implications for rehabilitation of TSFs containing these materials. 


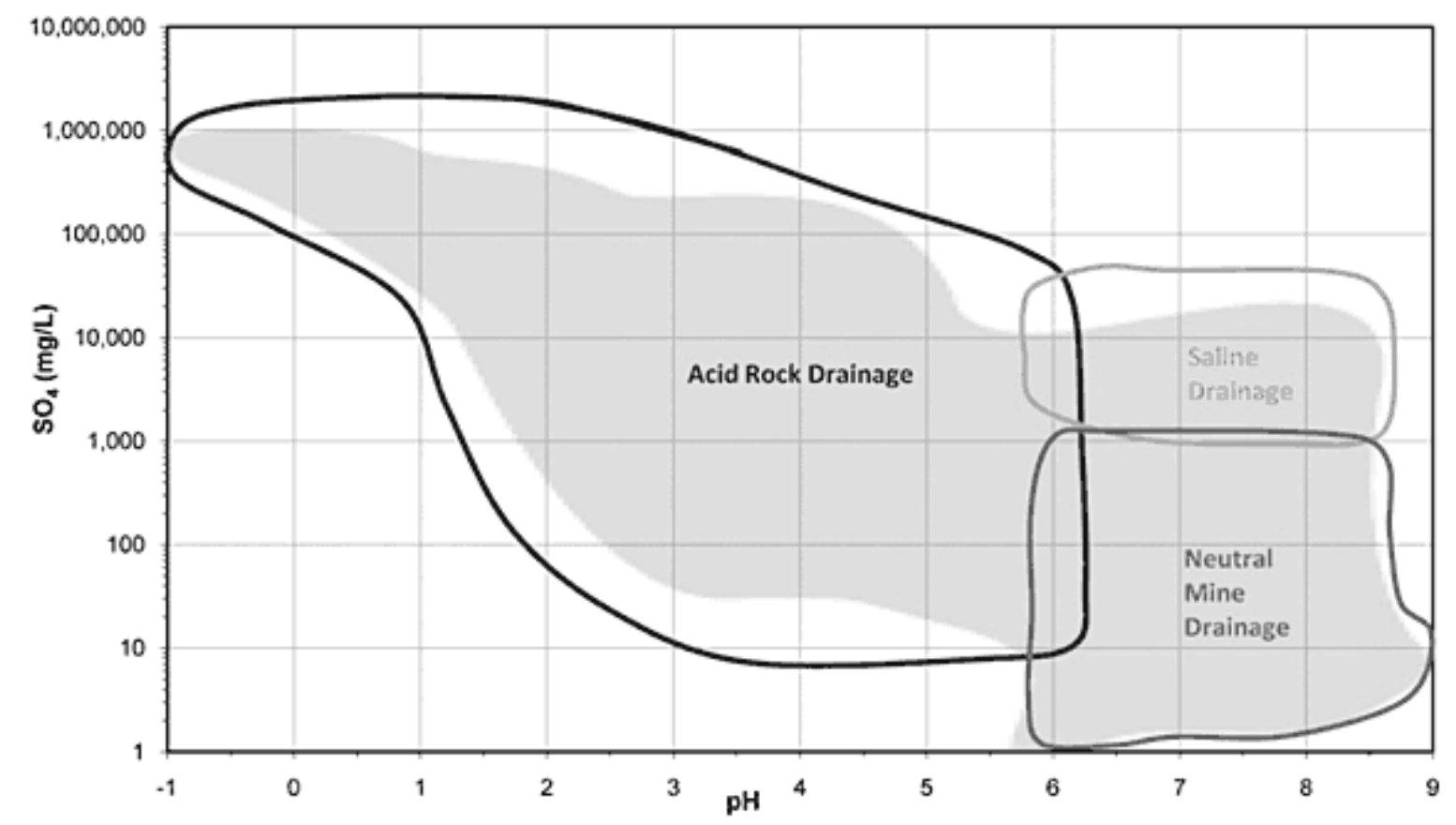

Figure 1 Diagram showing ARD, NMD and SD as a function of $\mathrm{pH}$ and sulphate concentrations (from GARD Guide, 2010)

\section{Materials characterisation}

\subsection{Tailings}

\subsubsection{Acid base accounting}

Samples of tailings were collected from the surface $(0-100 \mathrm{~mm})$ at 16 locations within the TSF and analysed for ARD characterisations using standard acid-base accounting procedures (DITR, 2007). Maximum potential acidity (MPA) was calculated from the concentration of non-sulphate sulphur, which in turn was calculated from the difference between total sulphur and sulphate-sulphur. This method assumes that most of the non-sulphate-sulphur is present as iron sulphides, which generate acidity upon oxidation. Apart from residual lead sulphide (galena) and zinc sulphide (sphalerite), which are do not generate acid when oxidised, the dominant sulphide was identified as marcasite $\left(\mathrm{FeS}_{2}\right)$.

Acid neutralising capacity (ANC) was measured by the classical Sobek method (Sobek et al., 1978). The samples were also analysed for total carbonate to provide an estimate of the calcium carbonate content, the dominant acid-consuming mineral in the tailings.

Net acid production potential (NAPP) was calculated as the difference between MPA and ANC. Negative NAPP values indicated the tailings were likely to be Non Acid Forming (NAF).

Results for analysis of the surface tailings are presented in Table 1.

Negative values for NAPP clearly demonstrate that the tailings are NAF. Other information provided by the AMD assessment was:

- Almost all of the ANC is provided by calcium carbonate. Based on the mean value of $10.74 \%$ for total carbon, the calcium carbonate content is estimated to be $89 \%$.

- Approximately $20 \%$ of the total sulphur is present in the fully oxidised sulphate form. The remaining $80 \%$ is present mainly as unoxidised marcasite.

The amount of ANC in the tailings exceeds the maximum amount of acid that can be generated by complete oxidation of the sulphides by a factor of seven. 
Table 1 Results for AMD characterisation of surface tailings

\begin{tabular}{|c|c|c|c|c|c|c|c|c|}
\hline \multicolumn{2}{|c|}{ Analyte } & $\mathbf{C}$ & $\mathbf{S}$ & $\mathrm{S}^{-\mathrm{SO}_{4}}$ & $\begin{array}{c}\mathrm{Non} \\
\mathrm{SO}_{4}-\mathrm{S}\end{array}$ & ANC & MPA & NAPP \\
\hline \multicolumn{2}{|c|}{ Units } & $\%$ & $\%$ & $\%$ & $\%$ & \multicolumn{3}{|c|}{$\mathrm{kg} \mathrm{H}_{2} \mathrm{SO}_{4} /$ Tonne } \\
\hline $\begin{array}{c}\text { Sample } \\
\text { Location }\end{array}$ & $\begin{array}{c}\text { Sample } \\
\text { Depth } \\
\text { (mm) }\end{array}$ & & & & & & & \\
\hline TS1 & $0-100$ & 10.03 & 6.666 & 1.49 & 5.176 & 771 & 159 & -612 \\
\hline TS2 & $0-100$ & 10.41 & 5.742 & 0.99 & 4.752 & 813 & 146 & -667 \\
\hline TS3 & $0-100$ & 10.21 & 6.789 & 1.49 & 5.299 & 775 & 162 & -613 \\
\hline TS4 & $0-100$ & 10.62 & 4.522 & 1.44 & 3.082 & 819 & 94 & -725 \\
\hline TS5 & $0-100$ & 9.93 & 6.612 & 1.92 & 4.692 & 765 & 144 & -621 \\
\hline TS6 & $0-100$ & 9.61 & 7.642 & 1.99 & 5.652 & 732 & 173 & -559 \\
\hline TS7 & $0-100$ & 10.45 & 5.135 & 1.34 & 3.795 & 816 & 116 & -700 \\
\hline TS8 & $0-100$ & 10.56 & 6.540 & 0.70 & 5.840 & 823 & 179 & -644 \\
\hline TS9 & $0-100$ & 11.10 & 3.581 & 0.60 & 2.981 & 868 & 91 & -777 \\
\hline TS10 & $0-100$ & 10.54 & 2.180 & 0.49 & 1.690 & 900 & 52 & -848 \\
\hline TS11 & $0-100$ & 11.45 & 2.612 & 0.35 & 2.262 & 894 & 69 & -825 \\
\hline TS12 & $0-100$ & 10.79 & 4.382 & 1.12 & 3.262 & 839 & 100 & -739 \\
\hline TS13 & $0-100$ & 11.47 & 2.954 & 0.21 & 2.744 & 899 & 84 & -815 \\
\hline TS14 & $0-100$ & 11.18 & 3.926 & 0.59 & 3.336 & 869 & 102 & -767 \\
\hline TS15 & $0-100$ & 11.82 & 1.962 & 0.27 & 1.692 & 919 & 52 & -867 \\
\hline TS16 & $0-100$ & 11.59 & 2.442 & 0.35 & 2.092 & 910 & 64 & -846 \\
\hline Minimum & & 9.61 & 1.96 & 0.21 & 1.69 & 732 & 52 & -867 \\
\hline Maximum & & 11.82 & 7.64 & 1.99 & 5.84 & 919 & 179 & -559 \\
\hline Mean & & 10.74 & 4.61 & 0.96 & 3.65 & 838 & 112 & -726 \\
\hline Standard d & eviation & 0.65 & 1.89 & 0.59 & 1.42 & 58 & 43 & 99 \\
\hline
\end{tabular}

\subsubsection{Elemental composition}

Mean concentrations for major elements and potential contaminants provided by analysis of the 16 surface tailings samples using an acid (aqua regia) digestion procedure is presented in Table 2.

These results confirm that most of the ANC is provided by calcium carbonate. High concentrations of residual lead and zinc were recorded, along with significant amounts of arsenic, silver, cadmium and thallium. 
Table 2 Results for elemental composition of surface tailings

\begin{tabular}{lll|lll}
\hline Element & Units & Concentration & Element & Units & Concentration \\
\hline Calcium & $\%$ & 35.6 & Silver & $\mathrm{mg} / \mathrm{kg}$ & 2.8 \\
Carbon & $\%$ & 10.74 & Arsenic & $\mathrm{mg} / \mathrm{kg}$ & 37 \\
Aluminium & $\mathrm{mg} / \mathrm{kg}$ & 237 & Barium & $\mathrm{mg} / \mathrm{kg}$ & 96 \\
Iron & $\%$ & 3.53 & Cadmium & $\mathrm{mg} / \mathrm{kg}$ & 5.4 \\
Potassium & $\mathrm{mg} / \mathrm{kg}$ & 166 & Copper & $\mathrm{mg} / \mathrm{kg}$ & 30 \\
Manganese & $\mathrm{mg} / \mathrm{kg}$ & 962 & Mercury & $\mathrm{mg} / \mathrm{kg}$ & 0.01 \\
Magnesium & $\mathrm{mg} / \mathrm{kg}$ & 2,057 & Lead & $\mathrm{mg} / \mathrm{kg}$ & 1,744 \\
Sodium & $\mathrm{mg} / \mathrm{kg}$ & 166 & Antimony & $\mathrm{mg} / \mathrm{kg}$ & $<0.05$ \\
Sulphur & $\mathrm{mg} / \mathrm{kg}$ & 4.61 & Selenium & $\mathrm{mg} / \mathrm{kg}$ & $<2$ \\
Zinc & $\mathrm{mg} / \mathrm{kg}$ & 2,351 & Thallium & $\mathrm{mg} / \mathrm{kg}$ & 1.22 \\
\hline
\end{tabular}

\subsubsection{Neutral mine drainage assessment}

Tailings extracts for assessment of neutral mine drainage potential were prepared using the Australian Standard Leach Procedure (ASLP, Australian Standard AS4439.2/3). This procedure has been recently introduced to characterise urban and industrial wastes before disposal in appropriate land fill facilities. The test method has been designed to provide a test solution with water quality similar to that of seepage from land fill facilities. This study has shown that the procedure provides a very good indication of seepage water quality from TSFs and waste rock stockpiles containing NAF materials. A deionised water leach without $\mathrm{pH}$ adjustment was used to extract contaminants from samples of tailings collected from several profiles of tailings in the TSF to a depth of approximately $2.5 \mathrm{~m}$.

Leachates were analysed for alkalinity, pH, EC, $\mathrm{Ag}, \mathrm{Al}, \mathrm{As}, \mathrm{Ba}, \mathrm{Bi}, \mathrm{Ca}, \mathrm{Cd}, \mathrm{Cl}, \mathrm{Cu}, \mathrm{F}, \mathrm{Fe}, \mathrm{Hg}, \mathrm{K}, \mathrm{Mg}, \mathrm{Mn}$, $\mathrm{Na}, \mathrm{Pb}, \mathrm{S}, \mathrm{Sb}, \mathrm{Se}, \mathrm{Tl}$ and $\mathrm{Zn}$. A summary of the results for the analysis of surficial tailings $(0-100 \mathrm{~mm})$ for selected analytes is presented in Table 3 .

Table 3 Results for analysis of water leachates of surface tailings

\begin{tabular}{lllll}
\hline Analyte & Units & Minimum & Maximum & Mean \\
\hline $\mathrm{pH}$ & $\mathrm{pH} \mathrm{units}$ & 7.4 & 8.1 & 7.8 \\
$\mathrm{EC}$ & $\mathrm{mS} / \mathrm{cm}$ & 0.59 & 1.58 & 1.16 \\
Alkalinity & $\mathrm{mg} \mathrm{CaCO} / \mathrm{L}$ & 243 & 1,094 & 711 \\
Sulphate & $\mathrm{mg} / \mathrm{L}$ & 3,444 & 1,6065 & 10,147 \\
Chloride & $\mathrm{mg} / \mathrm{L}$ & 71 & 561 & 226 \\
Fluoride & $\mathrm{mg} / \mathrm{L}$ & 2 & 8 & 4.9 \\
Arsenic & $\mathrm{mg} / \mathrm{L}$ & $<0.005$ & 0.015 & - \\
Calcium & $\mathrm{mg} / \mathrm{L}$ & 1,509 & 6,819 & 4,163 \\
Cadmium & $\mathrm{mg} / \mathrm{L}$ & 0.001 & 0.011 & 0.005 \\
Lead & $\mathrm{mg} / \mathrm{L}$ & 0.05 & 1.63 & 0.41 \\
Selenium & $\mathrm{mg} / \mathrm{L}$ & $<0.03$ & $<0.03$ & $<0.03$ \\
Thallium & $\mathrm{mg} / \mathrm{L}$ & 0.0579 & 0.643 & 0.26 \\
Zinc & $\mathrm{mg} / \mathrm{L}$ & 0.1 & 21.1 & 4.0 \\
\hline
\end{tabular}


These results indicate that seepage from the tailings is expected to be slight alkaline and moderately saline, with the dominant soluble ions being calcium and sulphate. Analysis of profile samples suggests that the near-surface tailings contain precipitated gypsum $\left(\mathrm{CaSO}_{4} \cdot 2 \mathrm{H}_{2} \mathrm{O}\right)$. The metals most likely to be present in environmentally significant concentrations are zinc, lead and thallium. Relatively little arsenic and selenium are present in water leachates of surficial tailings. Soluble fluoride is present, although the dominant form is expected to be fluorite $\left(\mathrm{CaF}_{2}\right)$, which is only sparingly soluble in water.

\subsection{Soils}

Samples of soil from topsoil stockpiles, existing borrow pits and test pits excavated to identify suitable soil for rehabilitation purposes were fully characterised. Two distinct soils types were present; a red-orange gravelly calcareous loam and a black cracking light clay. Both soil types were alkaline, mainly non-saline, and moderately fertile and had low potential for dispersion. Concentrations of heavy metal toxicants were very low. A summary of the thallium data is presented in Table 4. Most samples had thallium concentrations several orders of magnitude lower than those of the tailings.

Table 4 Summary of thallium concentration in soil

\begin{tabular}{lllll}
\hline Description & $\begin{array}{l}\text { No. of } \\
\text { Samples }\end{array}$ & $\begin{array}{l}\text { Minimum } \\
\mathbf{m g} / \mathbf{k g}\end{array}$ & $\begin{array}{l}\text { Maximum } \\
\mathbf{m g} / \mathbf{k g}\end{array}$ & $\begin{array}{l}\text { Median } \\
\mathbf{m g} / \mathbf{k g}\end{array}$ \\
\hline Topsoils & 8 & $<0.00005$ & 0.00009 & 0.00006 \\
Subsoils & 14 & $<0.00005$ & 0.00074 & $<0.00005$ \\
Borrow pit soils & 5 & $<0.00005$ & 0.00172 & 0.00011 \\
\hline
\end{tabular}

\section{Thallium geochemistry}

\subsection{Thallium chemistry and toxicity}

Thallium is a heavy metal (Atomic Number 81) situated in group IIIA of the periodic table of elements between mercury and lead. The two main oxidation states are +1 and +3 . The ionic radius of the $\mathrm{Tl}^{+}$ion is 0.147 nanometres, which is similar to the $\mathrm{K}^{+}(0.133$ nanometres $)$ and $\mathrm{Ag}^{+}(0.126$ nanometres $)$ ions. The trivalent ion, $\mathrm{Tl}^{3+}$, is a moderately strong oxidising agent and therefore rarely encountered in nature.

Like many other heavy metals, thallium forms very insoluble sulphide minerals. However, when sulphides containing thallium are oxidised, most of the oxidation products (such as the hydroxide and carbonate) containing $\mathrm{Tl}^{+}$are moderately soluble and therefore leachable and potentially bioavailable. Table 5 compares solubility of common thallium salts with corresponding lead and zinc salts.

Table 5 Solubility products $\left(K_{\text {sp }}\right)$ for common thallium, lead and zinc compounds

\begin{tabular}{llllll}
\hline Metal & Sulphide & Chloride & Carbonate & Hydroxide & Sulphate \\
\hline Thallium $\left(\mathrm{Tl}^{+}\right)$ & $6 \times 10^{-22}$ & $1.86 \times 10^{-4}$ & Soluble & Soluble & Soluble \\
Lead $\left(\mathrm{Pb}^{2}+\right)$ & $3 \times 10^{-28}$ & $1.7 \times 10^{-5}$ & $7.4 \times 10^{-14}$ & $1.4 \times 10^{-20}$ & $2.5 \times 10^{-8}$ \\
Zinc $\left(\mathrm{Zn}^{2+}\right)$ & $2 \times 10^{-25}$ & Soluble & $1.5 \times 10^{-10}$ & $3 \times 10^{-17}$ & Soluble \\
\hline
\end{tabular}

Thallium is highly toxic within the environment with acute effects when absorbed in large amounts, including animal deaths and low growth rates in plants, or death. Acute effects are typically seen two to four days after animals or plants are initially exposed to excessive levels of thallium. Thallium has high acute toxicity to aquatic life (John Peter and Viraraghavan, 2005). The absence of water quality criteria for this element in the ANZECC 2000 water quality guidelines is due to its rarity and the absence of environmental impact information in an Australian context, and does not indicate that thallium is not a potential environmental hazard. 
There is very limited data available to evaluate the chronic effects of thallium on plants, birds or terrestrial animals. However, chronic effects may include shortened lifespan, reproductive problems, lower fertility and changes in appearance or behaviour in exposed animals. These effects can be seen long after the initial exposure. Thallium compounds can also be bioaccumulated within plant and animal tissue, causing chronic health problems to sensitive organisms, which can be transferred to other trophic levels.

The high toxicity of thallium is attributed to an affinity for sulphur-containing enzymes and resembles other heavy metals such as mercury and lead in this respect. The similarity of the $\mathrm{Tl}^{+}$and $\mathrm{K}^{+}$ions allows thallium to inhibit important biological functions controlled by potassium ions.

\subsection{Distribution of acid soluble thallium in tailings profiles}

The levels and distribution of acid-soluble thallium in profiles of four sampling sites in the TSF are shown in Figure 2. Concentrations in tailings ranged from approximately 3 to $11 \mathrm{mg}$ per $\mathrm{kg}$.

There is no systematic trend in concentrations of acid-soluble thallium with depth or location and the variation is believed to be indicative of the composition of the ore processed at that time.

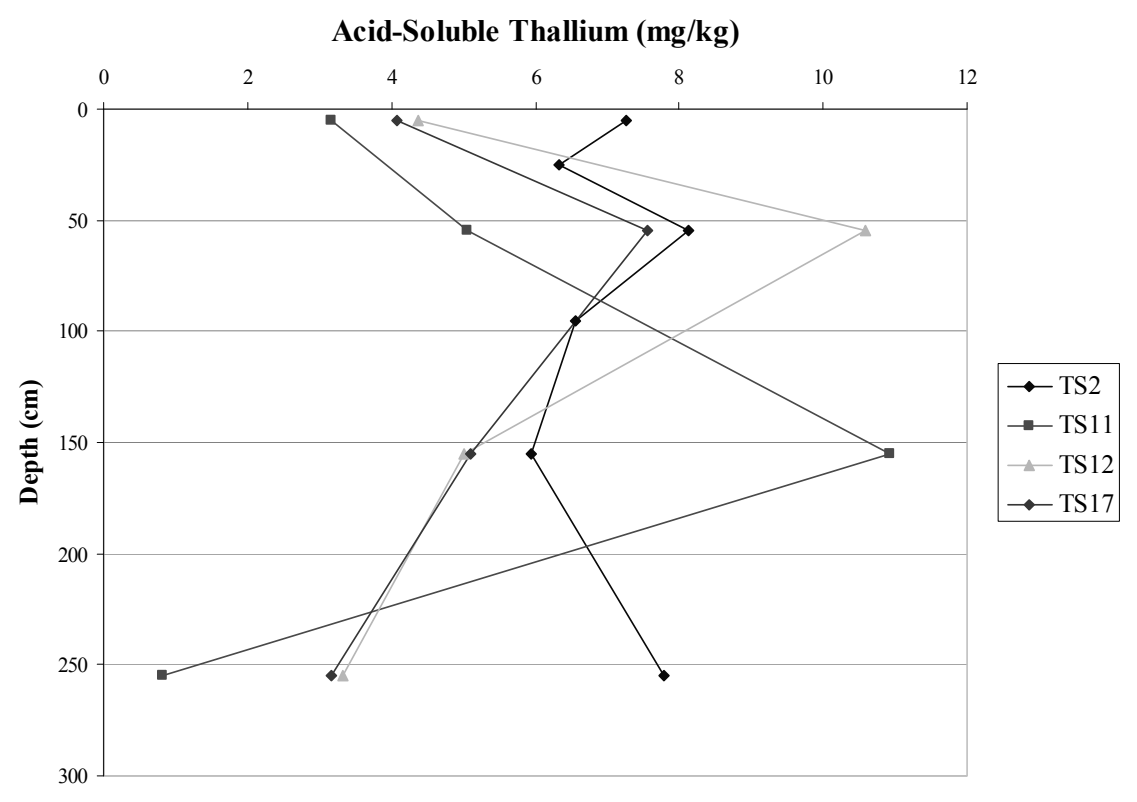

Figure 2 Profiles of acid-soluble thallium concentrations at four locations in the Pillara TSF

Statistical analysis of data for the elemental composition of tailings from these four locations indicates very high correlations with iron and sulphur, as shown by the values for the corresponding correlation coefficients presented in Table 6 . There was also a high negative correlation with calcium. These observations clearly demonstrate that thallium is associated with the sulphide mineralisation rather than calcite in the host limestone formations. Moderately significant correlations were recorded between thallium and elements including lead, arsenic and antimony rather than zinc and cadmium. This suggests that the thallium is more closely associated with galena $(\mathrm{PbS})$ rather than sphalerite $(\mathrm{ZnS})$. Galena is usually more resistant than sphalerite to oxidation and so most of the thallium is considered to be present in a moderately inert form.

The association of thallium with sulphide minerals is consistent with existing information in the literature as reviewed by Nriagu (1998) and references therein. 
Table 6 Correlations between concentrations of acid-soluble thallium and other elements in tailings

\begin{tabular}{lc}
\hline Element & $\begin{array}{c}\text { Correlation Coefficient } \\
\text { (r) }\end{array}$ \\
\hline Iron & 0.921 \\
Sulphur & 0.910 \\
Manganese & 0.861 \\
Silver & 0.717 \\
Copper & 0.509 \\
Arsenic & 0.489 \\
Lead & 0.422 \\
Antimony & 0.404 \\
Aluminium & -0.014 \\
Zinc & -0.133 \\
Cadmium & -0.211 \\
Sodium & -0.313 \\
Calcium & -0.884 \\
\hline
\end{tabular}

\subsection{Distribution of water soluble thallium in tailings profiles}

Although concentrations of total thallium are significantly lower than those of both lead and zinc, concentrations of water soluble forms of all three metals were similar. This result was not unexpected, given the higher solubility of thallium carbonate, hydroxide and sulphate compared to those of the corresponding lead and zinc compounds.

Examination of water leachate results for thallium from all tailings samples, to a maximum depth of $2.6 \mathrm{~m}$ collected over three years, indicate that significantly higher concentrations were recorded in samples at or near the surface of the TSF. This trend is evident from Figure 3, in which concentrations are plotted as a function of depth for samples collected at four locations within the TSF.

Although there is considerable variation, concentrations of thallium in porewater are of similar magnitude to those measured in water extracts of tailings. Porewater concentrations ranged from 0.00007 to $0.0141 \mathrm{mg} / \mathrm{L}$. Concentrations in water extracts of tailings samples collected at $250-260 \mathrm{~cm}$ depths, at which depth the tailings were saturated, from the corresponding locations varied from 0.0001 to $0.0047 \mathrm{mg} / \mathrm{L}$. 


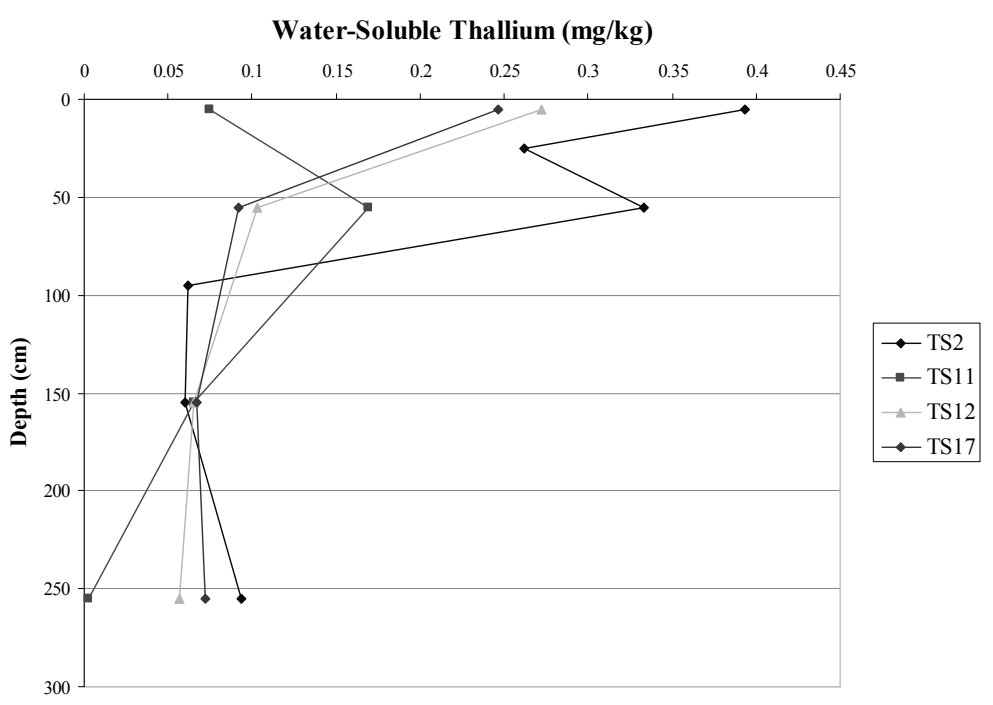

Figure 3 Profiles of water-soluble thallium concentrations

Statistical analysis of the data for water-soluble analytes showed a different trend to that of the acid-soluble elements, as shown in Table 7. In this case, water-soluble thallium was highly correlated with other watersoluble cations, especially magnesium, calcium and potassium. This suggests that soluble thallium released by slow oxidation of associated sulphide minerals will concentrate thallium with other water-soluble salts at the tailings surface prior to positioning of a designed soil cover. This was because the rate of upward solute transport by evaporo-transpiration related to diurnal concentration exceeds the rate of simple leaching as a result of rainfall.

\section{Table 7 Correlations between concentrations of water-soluble thallium and other ions in tailings}

\begin{tabular}{lc}
\hline Element & $\begin{array}{c}\text { Correlation Coefficient } \\
\text { (r) }\end{array}$ \\
\hline Magnesium & 0.780 \\
Calcium & 0.757 \\
Potassium & 0.717 \\
Sulphate & 0.693 \\
Cadmium & 0.634 \\
Arsenic & 0.631 \\
Sodium & 0.531 \\
Lead & 0.421 \\
Silver & 0.070 \\
Zinc & -0.099 \\
Antimony & -0.182 \\
\hline
\end{tabular}




\section{$4 \quad$ TSF rehabilitation trial}

\subsection{Trial design}

The final design of covers for each TSF considered the following geotechnical, environmental and geochemical factors relevant to each location:

- Both TSFs are 'paddock style', with large footprint areas.

- The maximum thickness of the soil cover is limited by the relatively small volumes of suitable soil types.

- As both mines were underground operations, the volumes of non-mineralised waste rock types were limited.

- Both mine sites are located in a subtropical environment in which most of the rainfall occurs in summer, including tropical cyclones. The covers were designed to shed most of the water from these intense rainfall events without causing erosion of the soil cover.

- Both mine sites are located on pastoral leases. Cattle will have access to the rehabilitated TSFs. Limestone spinifex (Triodia wiseana) is the preferred rehabilitation species as it is expected to provide stability to erosion and low palatability for livestock.

- The tailings are classified as AF. Sulphate is expected to be the dominant soluble contaminant formed by oxidation of the tailings.

Geochemical characterisation of the tailings clearly demonstrated that there was potential for soluble contaminants, particularly sulphates, lead, zinc, thallium and fluoride to enter the environment, either upwards through the cover by capillary rise or plant uptake, and downwards by accelerated leaching.

Following completion of mining operations, a trial was established on the TSF to compare performance of three different cover designs. The cover specification for each option is presented in Table 8 .

\subsection{Distribution of thallium in tailings and soil cover}

After a period of 12 months, covers incorporating either $400 \mathrm{~mm}$ of gravelly subsoil or $300 \mathrm{~mm}$ of gravelly subsoil over a $100 \mathrm{~mm}$ waste rock layer were found to be highly effective for preventing ingress of thallium from underlying tailings, as shown by Figure 4. Concentrations of soluble thallium had concentrated in a layer approximately $300 \mathrm{~mm}$ below the tailings surface, as had soluble calcium and sulphate (presumably in the form of gypsum). Concentrations of soluble thallium in the overlying soil were several orders of magnitude lower and similar to those listed in Table 4 for natural soils.

Table 8 Trial TSF cover design specifications

\begin{tabular}{llll}
\hline Cover Material & \multicolumn{3}{c}{ Cover Thickness (mm) } \\
& Option 1 & Option 2 & Option 3 \\
\hline Topsoil & $50-75$ & $50-75$ & $50-75$ \\
Gravelly/blocky subsoil & 400 & 300 & 200 \\
Limestone waste rock & 0 & 100 & 200 \\
\hline
\end{tabular}




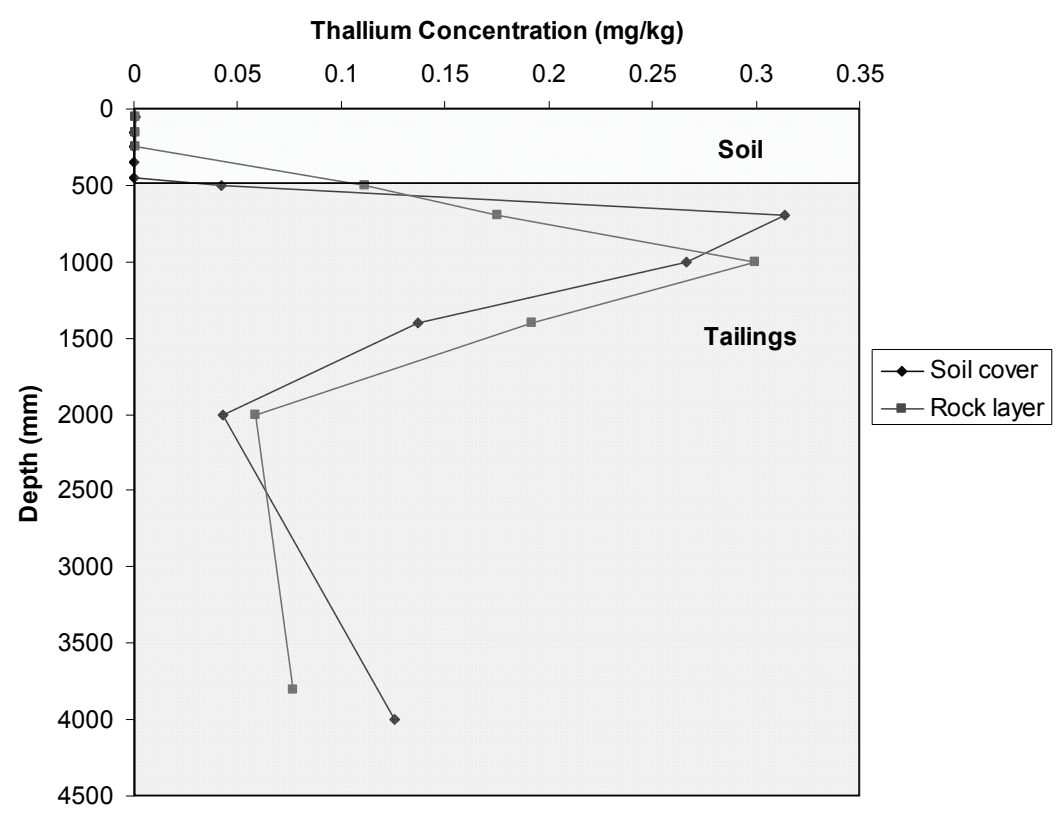

Figure 4 Profile of water-soluble thallium in TSF cover and tailings

\subsection{Plant uptake}

Samples of plants growing on the TSF cover trial, a TSF rehabilitated several years earlier and natural soils in the area were collected for analysis. There was no evidence to indicate that any of the plant species tested were hyperaccumulators of heavy metals or that plants growing on the TSF covers contained higher metal contents compared to those growing on natural soils.

\subsection{Seepage to groundwater}

Several groundwater monitoring bores were installed around each TSF to determine whether seepage of tailings fluids had impacted upon groundwater quality. Increased sulphate concentrations have been recorded in several bores, which indicates that some seepage has occurred. However, concentrations of heavy metals, especially thallium, have been very low. Lateral movement of metal ions through the natural soil, especially the black cracking clay, is expected to be very low. The black cracking clays have a high smectite clay content, which provides a very high cation exchange capacity (CEC). Cation exchange between thallium (and other metal ions) with calcium and magnesium on the soil exchange sites appears to be effective at removing thallium from solution.

\section{Conclusions}

In most circumstances, tailings containing almost $90 \%$ of calcium carbonate would be considered environmentally benign. Characterisation of lead-zinc tailings using procedures recommended by the Western Australian Department of Mines and Petroleum (DMP), which focus on potential for ARD generation, clearly demonstrate they are NAF. Elemental composition of these tailings indicated lead, zinc and arsenic were the elements with the highest potential for environmental contamination.

Comprehensive geochemical characterisation using methods to predict NMD water quality identified potential for thallium to be released in water soluble forms upon oxidation. This information was taken into account when designing an appropriate soil cover system to rehabilitate these TSFs upon completion of mining. To minimise potential for transfer of thallium (and other soluble toxicants) to the environment and livestock receptors, a cover design to minimise upward movement through the soil cover and leaching through the tailings was developed. Local soils and waste rock were shown to be suitable rehabilitation materials and their performance has been demonstrated in a cover trial prior to commissioning the final cover design. 


\section{References}

DITR (2007) Managing Acid and Metalliferous Drainage, Department of Industry, Tourism and Resources, February 2007.

GARD Guide (2010) Global Acid Rock Drainage Guide, The International Network for Acid Prevention, Section 2.4.1, http://www.gardguide.com/index.php/Main_Page (accessed 2 June 2010).

John Peter, A.L. and Viraraghavan, T. (2005) Thallium: a Review of Public Health and Environmental Concerns, Environmental International, Vol. 31, pp. 493-501.

Nriagu, J.O. (1998) Thallium in the Environment, Volume 29 in the series Advances in Environmental Science and Technology, John Wiley \& Sons Inc.

Sobek, A.A., Schuller, W.A., Freeman, J.R. and Smith, R.M. (1978) Field and Laboratory Methods Applicable to Overburdens and Minesoils, EPA-600/2-78-054. 
